\title{
The relation between some motoric and physiological characteristics of 13-15-year-old female volleyball players regarding their positions on the field (roles)
}

\author{
Serdar Eler ${ }^{1}$ \\ Nebahat Eler ${ }^{2}$
}

\begin{abstract}
The aim of this study was to determine the relation between some motoric and physiological characteristics of 13-15-year-old female volleyball players regarding their positions on the field. A total of 120 volleyball players have participated voluntarily. 30 of the participants whose mean age value was $14 \pm 0,76$ were setters; 30 of them were liberoes with mean age value of $13,8 \pm 0,45$; 30 of them were middle blockers with the mean age value of $14 \pm 0,79 ; 30$ of them were hitters with mean age value of $13.52 \pm 0,68$. The age, height, body weight, right-left hand gripping strength, vertical jump, throwing medicine ball, standing long jump, 30-second speed and body fat percentage measurements of the volleyball players have been performed. In evaluating the data, the One Way ANOVA has been used. No statistically significant differences have been determined between the age, weight right hand gripping strength and body fat percentage measurement results concerning the positions of the volleyball players, who participated in the study ( $p>0.05)$. On the other hand, it has been identified that there is a difference between the height, left hand gripping strength, throwing medicine ball, standing long jump, and speed values in terms of their positions $(p<0.05)$. The results of the study could be beneficial to evaluate the motoric and physiological characteristics of the volleyball players regarding their positions in establishing teams and in preparing training programs.
\end{abstract}

Keywords: Volleyball, female, position, motoric.

\section{Introduction}

Volleyball is a sports branch that attracts intense attention in terms of applicability and traceable among the team sports all over the world. Sustaining this status is directly related with the quality of the competitions; and therefore, with the play and the quality of the players.

Motoric and physiological profile plays important roles in physical performance of the volleyball players. Since there is a clockwise cycle in volleyball, each player has roles both in the front line and in the back line, and has specific responsibilities in terms of physical performance. Volleyball is a team sport that requires severe intensity with intervals; and activities of low intensity like stopping and walking at intervals. For this reason, players at a volleyball game show variable performances such as jumping, blocking, sprinting, and hitting (Malousaris, et al., 2008).

${ }^{1}$ Ph.D., Faculty of Sports Sciences, Gazi University, Ankara, serdareler@hotmail.com

2Ph.D., School of Physical Education and Sports, Bülent Ecevit University, Zonguldak, nebahateler@gmail.com 
Eler, S., \& Eler, N. (2017). The relation between some motoric and physiological characteristics of 13-15-year-old female volleyball players regarding their positions on the field (roles). Journal of Human Sciences, 14(4), 42654274. doi:10.14687/ihs.v14i4.5099

The performance improvement of volleyball players depend on technical, tactical, motoric and anthropometric factors. The players playing in various positions on the field have different capacities and characteristics and carry different responsibilities (Palao et al., 2014).

Nejić et al. (2013) conducted a study in which 56 volleyball players participated with the mean age values of $16.28 \pm 1.32$; and they compared the jumping performances of the players regarding their positions. No statistically significant differences in jumping values concerning positions were found $(\mathrm{p}>0.05)$.

The aim of this study is to determine the relation between the roles of the female volleyball players whose mean age value is 13-15, and their motoric and physiological characteristics. To the extent of our knowledge, there are not any studies in the literature conducted on this age group in this field in Turkey and in the world. Therefore the results of this study could be beneficial to evaluate the motoric and physiological characteristics of the players in terms of their positions in establishing teams and preparing training programs.

\section{Method}

120 female volleyball players, who played in various clubs between the ages of 13-15 and participated to the study voluntarily (Table 1). The tests applied to the players were performed twice, and the best values were determined. Before applying the tests to the players, the information regarding the use of any medicine and whether they had any injuries or not were asked and reported. The players, who participated in the study, were informed before the study, and each test was separately shown in an applicable manner. In order to ensure their participation at the required level, their motivation levels were increased.

Table 1. Definitive statistics of players.

\begin{tabular}{ccc}
\hline Position & $\mathrm{n}$ & $\%$ \\
\hline Setter & 30 & $25 \%$ \\
Libero & 30 & $25 \%$ \\
Middle Blocker & 30 & $25 \%$ \\
Hitter & 30 & $25 \%$ \\
\hline Total & 120 & $100 \%$ \\
\hline
\end{tabular}

Age: The ages of the players were determined as years according to the official registers recorded during interviews.

Measurement of the Body Height and Weight: The heights of the players were measured with Statiometer (SECA, Germany) whose sensitivity level was $0.01 \mathrm{~m}$; and the body weights of them were measured with electronic bascule (SECA, Germany) whose sensitivity level was 0.01 kg. During the height measurements, the players stood bare foot in straight position with minimal clothing, their heels joined, head straight, eyes looking forward. The caliper, which was sliding on the scale, was positioned to touch the head of the player, and the values were recorded. The weight measurements were made in a digital bascule, which was sensitive to 100 grams, and the players had tight and T-shirts in bare foot position.

The Handgrip Strength Test: The measurements were performed by using a Holtain-Brand hand dynamometer. The purpose of the test was to measure the force of forearm flexor muscles. The Grip Force test was used for the force indicator, which is one of the most important conditional factors. The hand dynamometer was adjusted according to the hand sizes of the players, and the players tried to tighten the dynamometer as much as they could while the arm in 10-150 angle with the shoulder on the side without bending the elbow. After 3 trials with both hands, the best performance of the player was determined. The dynamometer was reset after each trial, and the best performance was included in the evaluation. 
Eler, S., \& Eler, N. (2017). The relation between some motoric and physiological characteristics of 13-15-year-old female volleyball players regarding their positions on the field (roles). Journal of Human Sciences, 14(4), 42654274. doi:10.14687/jhs.v14i4.5099

Vertical Jump Test: The vertical jump tests were performed by using the jumping platform (Newtest, Finland) on which the flight and contact to the ground times were measured. It was ensured that the jumping height over the flying time, and depending on this, the forces of blasting force of the leg extensor muscles were determined for vertical jump tests. The highest value was taken into consideration after both trials.

The tip of one of the feet of the player stood $100 \mathrm{~cm}$ behind the starting point (in order to prevent any closeness to the photocell), knees were bent slightly, and the body was slightly leaning forward. When the player was ready, she departed with all her strength, and tried to pass the finish point as soon as possible with the highest speed possible. The results of the players were recorded; and after two trials, the best result was chosen.

Throwing Medicine Ball Test: The aim in this test is to determine the blasting strength of the arm muscles. The test was performed with a medicine ball weighing $2 \mathrm{~kg}$. An area with open front side was determined, and a throwing line was drawn. The player stood on her knees right behind the starting point where the measurement would be made by opening her knees in shoulder length. Both knees were parallel to each other. The medicine ball was held by both hands and brought to the back of the head. After the body was bent slightly backwards, the hands were thrown forward, and the ball was let go at the farthest point over the head. Two trials were made with a few minutes' intervals and the best results were recorded.

Standing Long Jump Test: In order to perform this test, a steel meter with the brand "Celikler" was used. The players stood behind a line on a suitable ground that was not slippery, and waited by opening feet in shoulder length. When they were ready, they brought their both hands backwards, and in the meantime, bent their knees. With the forward movement of the arms, they jumped to the possible furthest point on a plain ground and fell. The starting point and the trace the player left on the line were taken as bases, and two trials were made for each players. The best result was recorded.

The height of the players was recorded as "m", the body weight as "kg", the 30-meter sprint as "s", the standing long jump as " $\mathrm{m}$ ", the vertical jump as "cm", the throwing weight ball as " $\mathrm{m}$ ", vertical jump left as "cm", and the hand grip force measurement was recorded as kg.

30-m Sprinting Test: The measurements in 30-m sprinting were made with Newtest, Finlandbrand photocell. The measurement was made on a plain ground, and the length of the race track was determined as 30 meters. A sufficient distance was provided as stopping area after the finish line. The race track distance and the characteristics of the ground were the same for all participants. The start and finish points were defined with a straight line on the ground. Photocells were placed at the start and 30-m finish points. In addition, the start and finish points were determined with signs (funnels, etc.).

\section{Body Fat Percentage Measurement}

Triceps Skinfold Thickness: The middle point between the acremion and olecranon eminentia of the vertical curve on the back-middle line behind the forearm (upper part of the triceps) was measured vertically by holding the fold of the skin on the muscle.

Biceps Skinfold Thickness: It was measured at the middle points of the shoulder and elbow on the front part of the arm over the biceps brachi muscle by holding the skinfold vertically.

Subscapula Skinfold Thickness: It was measured when the arm was left downwards freely, and the body was relaxed, parallel to the lateral of the bone right before the scapula by holding the skinfold diagonally.

Suprailiac Skinfold Thickness: It was measured by holding the skinfold, which was taken from the upper part of the ilium on the lateral-middle line of the body, in a slightly diagonal position.

Calf Skinfold Thickness: The player placed her leg muscles on a high place with an angle of 90o without stretching them. The measurement was taken from the medial surface over the middle line that separated the calf to two sides as the front and the rear part. The skinfold was held vertically from the widest part of the calf and the compass was held parallel to the ground. 
Eler, S., \& Eler, N. (2017). The relation between some motoric and physiological characteristics of 13-15-year-old female volleyball players regarding their positions on the field (roles). Journal of Human Sciences, 14(4), 42654274. doi: $10.14687 /$ jhs.v14i4.5099

Skinfold Thickness Measurements: In Skinfold measurement, a Holtain-brand skinfold caliper, which applied $10 \mathrm{~g} / \mathrm{sq} \mathrm{mm}$ pressure at every angle and which had 0,2 $\mathrm{mm}$ levels, was used. The Siri Formula was applied in measuring the body fat percentage (Tamer, 2000).

Statistical Analysis: SPSS 20 software program (SPSS Inc., Chicago IL, USA) was used for statistical analysis. Descriptive statistics as well as the Kolmogorov Smirnov test was used for the normality of the data. One-Way ANOVA was used for variables including more than two groups. Bonferroni test was used for multiple comparisons. Significance was set at $\mathrm{p}<0.05$.

\section{Results}

Table 2. Descriptive Statistics of Some Motoric and Physiological Characteristics of the Volleyball Players regarding their Positions

\begin{tabular}{|c|c|c|c|c|c|c|}
\hline & Position & $\mathrm{N}$ & Mean & Std. Deviation & Min. & Max. \\
\hline \multirow{4}{*}{ Age (year) } & Setter & 30 & 14 & 0,76 & 13 & 15 \\
\hline & Libero & 30 & 13,8 & 0,45 & 13 & 14 \\
\hline & Middle Blocker & 30 & 14 & 0,79 & 13 & 15 \\
\hline & Hitter & 30 & 13,52 & 0,68 & 13 & 15 \\
\hline \multirow{4}{*}{ Height (cm) } & Setter & 30 & 168,19 & 5,89 & 158,3 & 175,6 \\
\hline & Libero & 30 & 161,06 & 4,24 & 155,6 & 165,7 \\
\hline & Middle Blocker & 30 & 170,89 & 5,06 & 158,4 & 179,4 \\
\hline & Hitter & 30 & 168,44 & 4,7 & 158,6 & 177,4 \\
\hline \multirow{4}{*}{ Weight (kg) } & Setter & 8 & 61,56 & 3,55 & 56,5 & 65,3 \\
\hline & Libero & 5 & 55,22 & 5,15 & 49,5 & 61,3 \\
\hline & Middle Blocker & 30 & 61,02 & 6,94 & 49,85 & 75,41 \\
\hline & Hitter & 31 & 59,12 & 5,63 & 48,24 & 70,58 \\
\hline \multirow{4}{*}{$\begin{array}{l}\text { Right hand grip } \\
\text { strength (kg) }\end{array}$} & Setter & 30 & 32,92 & 2,05 & 29,92 & 36,81 \\
\hline & Libero & 30 & 27,13 & 1,18 & 25,24 & 28,34 \\
\hline & Middle Blocker & 30 & 30,27 & 2,29 & 25,96 & 34,15 \\
\hline & Hitter & 30 & 31,6 & 2,45 & 25,5 & 35,29 \\
\hline \multirow{4}{*}{$\begin{array}{l}\text { Left hand grip } \\
\text { strength (kg) }\end{array}$} & Setter & 30 & 31,35 & 1,24 & 28,84 & 32,71 \\
\hline & Libero & 30 & 26,64 & 0,88 & 25,13 & 27,34 \\
\hline & Middle Blocker & 30 & 29,04 & 2,4 & 24,16 & 33,15 \\
\hline & Hitter & 30 & 29,67 & 2,31 & 24,18 & 34,17 \\
\hline \multirow{4}{*}{ Vertical Jump (cm) } & Setter & 30 & 27,79 & 3,7 & 21,9 & 33,5 \\
\hline & Libero & 30 & 24,7 & 2,73 & 22,4 & 28,2 \\
\hline & Middle Blocker & 30 & 32,27 & 2,9 & 26,8 & 36,1 \\
\hline & Hitter & 30 & 34,86 & 3,23 & 28,2 & 41,2 \\
\hline \multirow{4}{*}{$\begin{array}{c}\text { Throwing } \\
\text { medicine ball (m) }\end{array}$} & Setter & 30 & 4,7 & 0,14 & 4,44 & 4,86 \\
\hline & Libero & 30 & 4,5 & 0,21 & 4,58 & 4,91 \\
\hline & Middle Blocker & 30 & 4,5 & 0,23 & 3,75 & 4,8 \\
\hline & Hitter & 30 & 4,1 & 0,08 & 4,15 & 4,8 \\
\hline \multirow{4}{*}{$\begin{array}{l}\text { Standing long } \\
\text { jump }(\mathrm{cm})\end{array}$} & Setter & 30 & 159,3 & 8,14 & 148 & 170 \\
\hline & Libero & 30 & 173,8 & 2,78 & 171 & 178 \\
\hline & Middle Blocker & 30 & 174,03 & 13,09 & 145 & 193 \\
\hline & Hitter & 30 & 174,81 & 11,68 & 146 & 191 \\
\hline \multirow{4}{*}{ Speed (sec) } & Setter & 30 & 5,04 & 0,1 & 4,92 & 5,18 \\
\hline & Libero & 30 & 4,97 & 0,1 & 4,85 & 5,1 \\
\hline & Middle Blocker & 30 & 5,26 & 0,35 & 4,75 & 6,03 \\
\hline & Hitter & 30 & 5,03 & 0,12 & 4,75 & 5,22 \\
\hline \multirow{4}{*}{$\begin{array}{c}\text { Body fat } \\
\text { percentage }(\%)\end{array}$} & Setter & 30 & 23,3 & 1,68 & 20,1 & 25,3 \\
\hline & Libero & 30 & 23,34 & 1,54 & 21,4 & 25,1 \\
\hline & Middle Blocker & 30 & 22,21 & 1,56 & 19,4 & 25,2 \\
\hline & Hitter & 30 & 22,89 & 1,15 & 21,1 & 25,5 \\
\hline
\end{tabular}


Eler, S., \& Eler, N. (2017). The relation between some motoric and physiological characteristics of 13-15-year-old female volleyball players regarding their positions on the field (roles). Journal of Human Sciences, 14(4), 42654274. doi:10.14687/jhs.v14i4.5099

Table 3. Comparison of the Players in terms of Some Motoric and Physiological Characteristics regarding their Positions in the Field

\begin{tabular}{|c|c|c|c|c|c|c|c|}
\hline & Position & $\mathrm{N}$ & Mean & $\begin{array}{c}\text { Std. } \\
\text { Deviation }\end{array}$ & $\mathrm{F}$ & Sig. & Diff. \\
\hline \multirow{4}{*}{ Age (year) } & Setter & 8 & 14 & 0,76 & \multirow{4}{*}{2,553} & \multirow{4}{*}{0,062} & \\
\hline & Libero & 5 & 13,8 & 0,45 & & & \\
\hline & Middle Blocker & 30 & 14 & 0,79 & & & \\
\hline & Hitter & 31 & 13,52 & 0,68 & & & \\
\hline \multirow{4}{*}{ Height (cm) } & Setter & 8 & 168,19 & 5,89 & \multirow{4}{*}{5,916} & \multirow{4}{*}{$0,001^{*}$} & \\
\hline & Libero & 5 & 161,06 & 4,24 & & & $2-3$ \\
\hline & Middle Blocker & 30 & 170,89 & 5,06 & & & $2-4$ \\
\hline & Hitter & 31 & 168,44 & 4,7 & & & \\
\hline \multirow{4}{*}{ Weight (kg) } & Setter & 8 & 61,56 & 3,55 & \multirow{4}{*}{1,725} & \multirow{4}{*}{0,17} & \\
\hline & Libero & 5 & 55,22 & 5,15 & & & \\
\hline & Middle Blocker & 30 & 61,02 & 6,94 & & & \\
\hline & Hitter & 31 & 59,12 & 5,63 & & & \\
\hline \multirow{4}{*}{$\begin{array}{l}\text { Right hand grip } \\
\text { strength (kg) }\end{array}$} & Setter & 8 & 32,92 & 2,05 & \multirow{4}{*}{8,305} & \multirow{4}{*}{$0,000^{*}$} & $1-2$ \\
\hline & Libero & 5 & 27,13 & 1,18 & & & $1-3$ \\
\hline & Middle Blocker & 30 & 30,27 & 2,29 & & & $2-3$ \\
\hline & Hitter & 31 & 31,6 & 2,45 & & & $2-4$ \\
\hline \multirow{4}{*}{$\begin{array}{l}\text { Left hand grip } \\
\text { strength (kg) }\end{array}$} & Setter & 8 & 31,35 & 1,24 & \multirow{4}{*}{5,129} & \multirow{4}{*}{$0,002^{*}$} & $1-2$ \\
\hline & Libero & 5 & 26,64 & 0,88 & & & $1-3$ \\
\hline & Middle Blocker & 30 & 29,04 & 2,4 & & & $2-3$ \\
\hline & Hitter & 31 & 29,67 & 2,31 & & & $2-4$ \\
\hline \multirow{4}{*}{$\begin{array}{l}\text { Vertical Jump } \\
\qquad(\mathrm{cm})\end{array}$} & Setter & 8 & 27,79 & 3,7 & \multirow{4}{*}{22,377} & \multirow{4}{*}{$0.000^{*}$} & $1-3$ \\
\hline & Libero & 5 & 24,7 & 2,73 & & & $1-4$ \\
\hline & Middle Blocker & 30 & 32,27 & 2,9 & & & $2-3$ \\
\hline & Hitter & 31 & 34,86 & 3,23 & & & $2-4 / 3-4$ \\
\hline \multirow{4}{*}{$\begin{array}{l}\text { Throwing medicine } \\
\text { ball }(\mathrm{m})\end{array}$} & Setter & 8 & 4,7 & 0,14 & \multirow{4}{*}{3,582} & \multirow{4}{*}{$0,018^{*}$} & $1-3$ \\
\hline & Libero & 5 & 4,5 & 0,21 & & & $1-4$ \\
\hline & Middle Blocker & 30 & 4,5 & 0,23 & & & $4-3$ \\
\hline & Hitter & 31 & 4,71 & 0,08 & & & $4-2$ \\
\hline \multirow{4}{*}{$\begin{array}{l}\text { Standing long } \\
\text { jump }(\mathrm{cm})\end{array}$} & Setter & 8 & 159,3 & 8,14 & \multirow{4}{*}{4,015} & \multirow{4}{*}{$0,010^{*}$} & \\
\hline & Libero & 5 & 173,8 & 2,78 & & & $1-3$ \\
\hline & Middle Blocker & 30 & 174,03 & 13,09 & & & $1-4$ \\
\hline & Hitter & 31 & 174,81 & 11,68 & & & \\
\hline \multirow{4}{*}{ Speed (sn) } & Setter & 8 & 5,04 & 0,1 & & & \\
\hline & Libero & 5 & 4,97 & 0,1 & 5,398 & $0,002 *$ & $3-4$ \\
\hline & Middle Blocker & 30 & 5,26 & 0,35 & & & \\
\hline & Hitter & 31 & 5,03 & 0,12 & & & \\
\hline & Setter & 8 & 23,3 & 1,68 & & & \\
\hline Body fat & Libero & 5 & 23,34 & 1,54 & 2,201 & 0,096 & \\
\hline percentage $(\%)$ & Middle Blocker & 30 & 22,21 & 1,56 & & & \\
\hline & Hitter & 31 & 22,89 & 1,15 & & & \\
\hline
\end{tabular}

When the results of the volleyball players were examined; it was observed that the average heights of the Liberoes are shorter than the Middle Blocker and Hitters; and there is a significant difference between them $(\mathrm{p}<0.05)$. According to the standing long jump measurement results, there is a significant difference in favor of the Hitters and Middle Blockers. 
Eler, S., \& Eler, N. (2017). The relation between some motoric and physiological characteristics of 13-15-year-old female volleyball players regarding their positions on the field (roles). Journal of Human Sciences, 14(4), 42654274. doi: $10.14687 /$ jhs.v14i4.5099

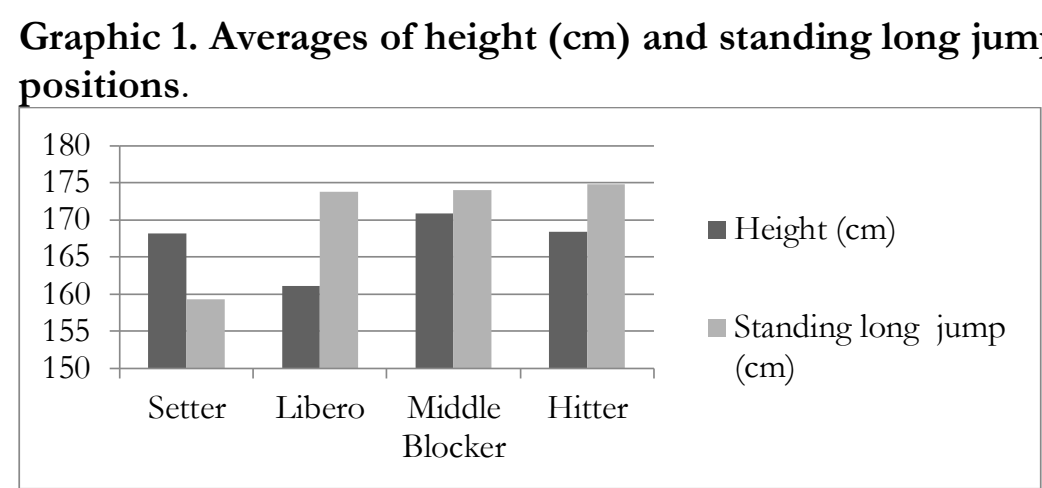

There is a significant difference among the players in favor of the Liberoes in Speed values when compared with the players from other positions $(p<0.05)$. When the throwing medicine ball measurement results were examined it is observed that there is a significant difference in favor of the Setter and Hitters $(\mathrm{p}<0.05)$.

Graphic 2. Averages of speed (sn) and throwing medicine ball (m) values regarding positions.

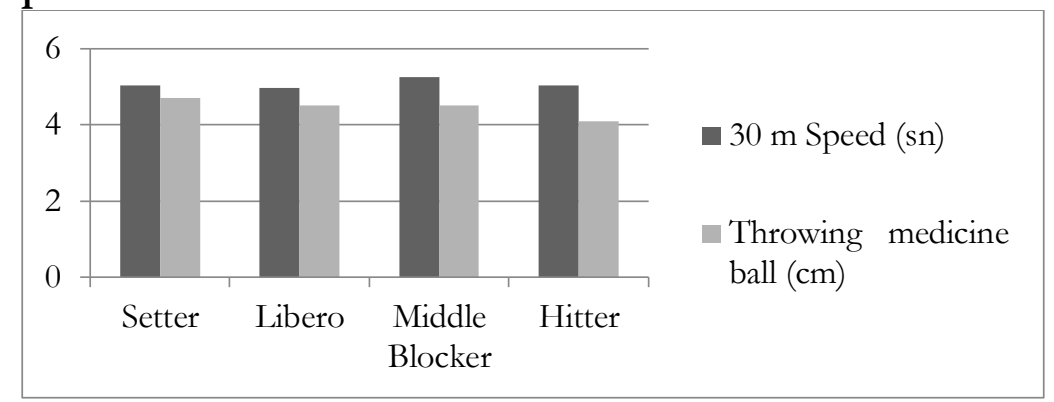

According to the findings obtained with the measurements conducted to determine left hand grip strength, a statistically significant difference was observed in favor of the Setters when compared with the players of the other positions $(\mathrm{p}<0.05)$. The vertical jump measurement average values of the Hitters were found to be higher than the Setters, Liberoes and Middle Blockers, and it has been understood that there is a significant difference $(\mathrm{p}<0.05)$.

Graphic 3. Averages of left hand grip strength (kg) and vertical jump (cm) values regarding positions.

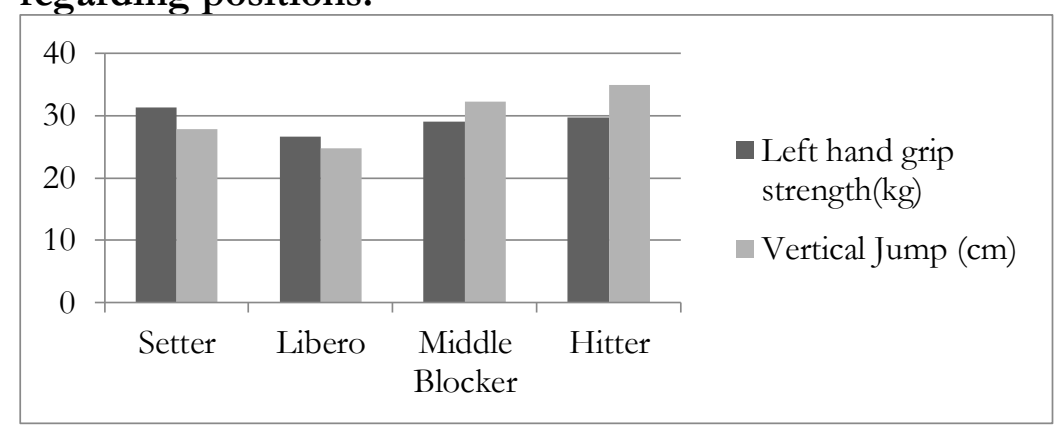

When graphic 3 is taken into consideration, no significant differences were determined between among the age, weight, right hand grip strength and body fat percentage measurement results of the volleyball players according to regarding their playing positions $(\mathrm{p}>0.05)$. 
Eler, S., \& Eler, N. (2017). The relation between some motoric and physiological characteristics of 13-15-year-old female volleyball players regarding their positions on the field (roles). Journal of Human Sciences, 14(4), 42654274. doi:10.14687/ihs.v14i4.5099

\section{Discussion}

Volleyball is a sport that requires having various roles in different positions for special tactical performance (Afonso et al, 2010). The players must have some physical and physiological features in order to perform play these roles. Generally, the players are classified as middle blocker, hitter, setter and liberoes (Malousaris et al., 2008,). For a successful performance, the players playing at different positions need technical, tactical, physical and physiological differences (Carvajal et al., 2012). For example, height is more important for middle blockers because they have the responsibility of blocking the ball when compared with the other positions and the hitters must jump higher than the setters to turn the most difficult balls into efficient attacks and to perform blocking (Schaal, et al., 2013).

The average heights of the volleyball players, who played as setters, have been found to be $168,19 \pm 5,89 \mathrm{~cm}$; the average heights of the liberoes were found as $161,06 \pm 4,24 \mathrm{~cm}$, the middle blockers, as $170,89 \pm 5,06 \mathrm{~cm}$, the hitters, $168,44 \pm 4,70 \mathrm{~cm}$. Helveci (2005), reported that average height and weight of young female players were $172 \mathrm{~cm}$ and $58.04 \mathrm{~kg}$. Demirel (2005), determined that average height of female players were $170 \mathrm{~cm}$ and $62.56 \mathrm{~kg}$. Kilınç and Acar (2006) determined that the female national team players' average height was $182 \mathrm{~cm}$, while their average weight was $67.6 \mathrm{~kg}$. Kılıç and Binboğa (2012) detected that average height and weight of female players (15-17 ages) are $167 \mathrm{~cm}$ and $57.86 \mathrm{~kg}$. Sönmez (2006) determined that female volleyball players' average height values were $144 \mathrm{~cm}$, while these values for male players were $147 \mathrm{~cm}$ the average weight of female players was $36.4 \mathrm{~kg}$. Concerning the averages height and weight of the players Nikolaidis et al. (2015) conducted a study and reported that the average heights of the middle blockers and hitters were higher than those of the liberoes $(n=62$, aged 15.6 \pm 1.1 years). Mielgo-Ayuso et al. conducted a study and reported that the average height values of the middle blockers were higher $(186.5 \pm 1.4 \mathrm{~cm})$, and those of the liberoes were shorter $(166.7 \pm 8.1 \mathrm{~cm})$. These results are similar of the present study. The right hand grip strength test average points of the volleyball players, who are setters, have been found to be $32,92 \pm 2,05 \mathrm{~kg}$; and those of the liberoes have been found as $27,13 \pm 1,18 \mathrm{~kg}$; those of the middle blockers have

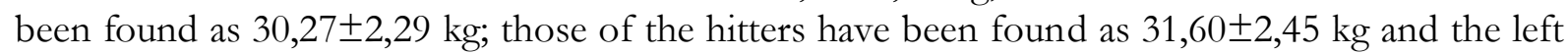
hand grip strength test average points of the volleyball players, who are setters, have been found to be $31,35 \pm 1,24 \mathrm{~kg}$; those of liberoes have been found as $26,64 \pm 0,88 \mathrm{~kg}$; those of the middle blockers have been found as $29,0 \pm 2,40 \mathrm{~kg}$; those of the hitters have been found as $29,67 \pm 2,31$ $\mathrm{kg}$. The difference between the middle blockers and hitters has been found to be statistically significant in favor of the setters; and the difference between the liberoes and the other players has also been found to be statistically significant in favor of the middle blockers and hitters $(\mathrm{p}<0.05)$. Klliç and Binboğa (2012) has reported that right handgrip strength of volleyball players were $29.03 \mathrm{~kg}$, while left handgrip strength of volleyball players were $28.23 \mathrm{~kg}$. In another study, Demirel (2005), have reported female volleyball players' right handgrip strength were $28.10 \mathrm{~kg}$, while their left handgrip strength were $27.08 \mathrm{~kg}$. Nikolaidis et al. (2015) conducted a study and reported that there was no difference between the positions of the players' handgrip strength $(\mathrm{p}>0.05)$.

The vertical jump test average points of the volleyball players, who played as setters, have been found as $27,79 \pm 3,70 \mathrm{~cm}$; those of the liberoes have been found as $24,7 \pm 2,73 \mathrm{~cm}$; those of the middle blockers have been found as $32,27 \pm 2,9 \mathrm{~cm}$; those of the hitters have been found as $34,86 \pm 3,23 \mathrm{~cm}$. the vertical jump average points of the hitters have been found higher than those of the setters, liberoes and middle blockers, and there is difference between them in favor of the hitters $(p<0.05)$. In a study by Önder $(2007)$ elite female volleyball players' linear jumping distance was determined to be $27.0 \mathrm{~cm}$. Thissen-Milder et al (1991) has reported that vertical jump distance for female volleyball players in high schools was $43.6 \mathrm{~cm}$. Nejić (2013) (16.28土1.32 years and n-56) conducted a study and did not report any differences between the vertical jump 
Eler, S., \& Eler, N. (2017). The relation between some motoric and physiological characteristics of 13-15-year-old female volleyball players regarding their positions on the field (roles). Journal of Human Sciences, 14(4), 42654274. doi:10.14687/jhs.v14i4.5099

values of the volleyball players regarding their positions. They reported that these results stemmed from the fact that the height and body weights of the players were very close to each other, which was very important for vertical jump. Nikolaidis et al. (2015) reported that the vertical jump average points of the players were higher than those of the hitters, setters, middle blockers and liberoes (hitters $(31.0 \pm 5.0 \mathrm{~cm})$; middle blockers $(26.4 \pm 3.3 \mathrm{~cm})$; setters $(30.5 \pm 4.4 \mathrm{~cm})$; liberoes $(30.0 \pm 7.2 \mathrm{~cm}))$. The results show parallelism with the results of the present study. The throwing medicine ball test average results of the players who played as setters have been found as $4,70 \pm 0,14 \mathrm{~m}$; those of the liberoes, as $4,50 \pm 0,21 \mathrm{~m}$; those of the middle blockers, as $4,50 \pm 0,23 \mathrm{~m}$; those of the hitters, as $4,71 \pm 0,08 \mathrm{~m}$. A statistically significant difference has been found between the values of the middle blocker and hitters in favor of the setters and liberoes $(p<0.05)$. The reason of this finding is because the setters apply passing techniques, which are very important for hitters and setters, more than the other players.

The standing long jump test average points of the players, who played as Setters, have been found as $159,3 \pm 8,14 \mathrm{~cm}$; those of the liberoes have been found as $173,8 \pm 2,78 \mathrm{~cm}$; those of the middle blockers, as $174,03 \pm 13,09 \mathrm{~cm}$, those of the hitters, as $174,81 \pm 11,68 \mathrm{~cm}$. A statistically significant difference has been found between the values of the setters and liberoes in favor of the middle blockers and hitters $(p<0.05)$. It is considered that the middle blockers and hitters perform jumping more than the other players during the trainings and competitions, and therefore, these values have been determined to be higher.

The speed test average results of the volleyball players, who played as setters, have been found as $5,04 \pm 0,10 \mathrm{sec}$; those of the liberoes have been found as $4,97 \pm 0,10 \mathrm{sec}$; those of the middle blockers, as $5,26 \pm 0,35 \mathrm{sec}$; those of the hitters, as $5,03 \pm 0,12 \mathrm{sec}$. When the speed values are considered, it has been observed that the players who have the lowest average values are the liberoes, and those who have the highest values are the middle blockers. A statistically significant difference has been determined among the values of the middle blockers in favor of the setters, liberoes and hitters $(p<0.05)$. The liberoes are defense players, and they have to be quick, fast, active and they have to possess a good reaction time. In addition, it is considered that the speed values of the middle blockers are determined to be lower due to their physical features.

No statistically significant differences have been determined among the age, weight, right grip strength and body fat percentage measurement results of the volleyball players regarding their positions $(\mathrm{p}>0.05)$.

\section{Conclusion}

The relation between some motoric and physiological features of 13-15-year-old female volleyball players have been investigated in this study. There are significant differences in this age group among the height, right-left hand grip strength, vertical jump, throwing medicine ball, standing long jump, speed, and positions. According to the results, height is important for the middle blockers, the hitters must jump well, and the setters and libero players must have speed because of their responsibilities in the field. It has been observed in the study that the body weight, age, and body fat percentage are important factors in this age group. When the motoric features are considered, the jumping strength is an important factor in the hitters; they have to have tall girls' jumping strength and values in order to perform their duties in the field (hitting, blocking, attacking to difficult balls by jumping, attacking from the back field, etc.).

According to the results of the speed test, which is another motoric property, the values of the liberoes, setters and hitters have been found to be higher than those of the middle blockers. The middle blockers must distribute passes to turn the coming balls into attacks, the liberoes must meet the most difficult balls in the defense, the Hitters must catch middle block after reaching the balls; and attacking require that these players must have high speed features. It is considered that the height of the middle blockers is a disadvantage in terms of speed. 
Eler, S., \& Eler, N. (2017). The relation between some motoric and physiological characteristics of 13-15-year-old female volleyball players regarding their positions on the field (roles). Journal of Human Sciences, 14(4), 42654274. doi:10.14687/ihs.v14i4.5099

As it is observed in the Standing long jump test results, the values of the middle blockers and hitters are high, and they have significant differences between the other players. It is considered that these values are high because they are the players who jump the most during training or a competition (blocking, hitting, jumping and servicing, etc.).

The throwing medicine ball average values of the setters and hitters have been found to be high and significant when compared with the players of other positions.

The setters apply the finger-pass technique more than the other players, and work their shoulder, finger and arm muscles equally. The throwing medicine ball and grip strength values being higher in these players is significant.

As a conclusion, the relation between some physical and physiological features of 13-15year-old female volleyball players and their positions in the field has been investigated in this study. It is considered that this study will be a beneficial resource for trainers and sports scientists in determining the positions by considering the motoric features of the players and in organizing training programs.

\section{References}

Afonso, J., Mesquita, I., Marcelino, R., \& Silva, J. (2010). Analysis of the setter's tactical action in high-performance women's volleyball. Kinesiology, 42(1), 82-89.

Carvajal, W., Betancourt, H., León, S., Deturnel, Y., Martínez, M., Echevarría, I., ... \& Serviat, N. (2012). Kinanthropometric profile of Cuban women Olympic volleyball champions. MEDICC review, 14(2), 16-22.

Demirel, P. (2005) El Antropometrik Ölçümleri ve El Kavrama Kuvvetinin Farkel Spor Branslarnda Karşılaştımlması, Zonguldak Karaelmas Üniversitesi, Sağlık Bilimleri Enstitüsü, Anatomi Anabilim Dalı, Yüksek Lisans Tezi.

Helveci, G. (2005) Genç Kıそlarda Voleybol Sporunun Kemik Mineral Yoğunluğu ve Vü̈ut Kompozisyonu Üzerindeki Etkisi, Bolu Abant İzzet Baysal Üniversitesi, Sağlık Bilimleri Enstitüsü, Antrenörlük Eğitimi, Anabilim Dalı, Yüksek Lisans Tezi.

Kilic, I., \& Binboga, M. (2012). Investigation of structural and biomotoric features of young volleyball players and determining the position by discriminant analysis. Ovidius University Annals, Series Physical Education and Sport/Science, Movement and Health, 12(2), 142-152.

Kilinç, F., Acar, Z. (2006) Genç Milli ve Bir Kulübün Genç Takımında Oynayan Bayan Voleybolcuların Antropometrik ve Dikey Siçrama Performans Profillerinin İncelenmesi, 9.Uluslararası Spor Bilimleri Kongresi, Muğla.

Kutlay, E., Çayırlı, M., and Özkol, M.Z. (2003). 13-15 Yaş Bayan Voleybolcuların Bazı Anaerobik Güç Parametrelerinin incelenmesi, IX. Ulusal Spor Hekimliği Kongresi, Nevşehir.

Malousaris, G. G., Bergeles, N. K., Barzouka, K. G., Bayios, I. A., Nassis, G. P., \& Koskolou, M. D. (2008). Somatotype, size and body composition of competitive female volleyball players. Journal of science and medicine in sport, 11(3), 337-344.

Mielgo-Ayuso, J., Calleja-González, J., Clemente-Suárez, V. J., \& Zourdos, M. C. (2015). Influence of anthropometric profile on physical performance in elite female volleyballers in relation to playing position. Nutricion hospitalaria, 31(2), 849-857.

Nejić, D., Trajković, N., Stanković, R., Milanović, Z., \& Sporiš, G. (2013). A comparison of the jumping performance of female junior volleyball players in terms of their playing positions. Facta Universitatis. Series: physical dducation and sport, 11(2), 157-164.

Önder, H.U. (2007) Ankara Birinci Lig Takimlarinda Oynayan Bayan Voleybolcularn Baz̨ Fiæilksel ve Fiøyolojik Parametrelerinin İncelenmesi, Ankara, Gazi Üniversitesi, Sağllk Bilimleri Enstitüsü, Yüksek Lisans Tezi.

Palao, J. M., Manzanares, P., \& Valadés, D. (2014). Anthropometric, physical, and age differences by the player position and the performance level in volleyball. Journal of human kinetics, 44(1), 223-236. 
Eler, S., \& Eler, N. (2017). The relation between some motoric and physiological characteristics of 13-15-year-old female volleyball players regarding their positions on the field (roles). Journal of Human Sciences, 14(4), 42654274. doi: $10.14687 /$ jhs.v14i4.5099

Schaal, M., Ransdell, L. B., Simonson, S. R., \& Gao, Y. (2013). Physiologic performance test differences in female volleyball athletes by competition level and player position. The Journal of Strength \& Conditioning Research, 27(7), 1841-1850.

Sönmez, E. (2006) Adölesan Dönemi Voleybolcu Cocuklarn Antropometrik Ölçümlerini Belirleyip ve Sedanter Cocuklarla Karşılaştırlması, Elazı̆̆g, Fırat Üniversitesi, Sağlık Bilimleri Enstitüsü, Beden Eğitimi Ve Spor Ana Bilim Dalı, Yüksek Lisans Tezi.

T Nikolaidis, P., Afonso, J., Buśko, K., Ingebrigtsen, J., Chtourou, H., \& J Martin, J. (2015). Positional differences of physical traits and physiological characteristics in female volleyball players-the role of age. Kineziologija, 47(1), 75-81.

Tamer K. (2000) Sporda Fiz̨iksel-Fižyolojik Performansin Ölçülmesi ve Değerlendirilmesi. 2. Basım, Bağırgan Yayımevi, Ankara.

Thissen-Milder, M., \& Mayhew, J. L. (1991). Selection and classification of high school volleyball players from performance tests. The Journal of sports medicine and physical fitness, 31(3), 380-384. 